\title{
Albert Geyser's resignation speech on 03 September 1968
}

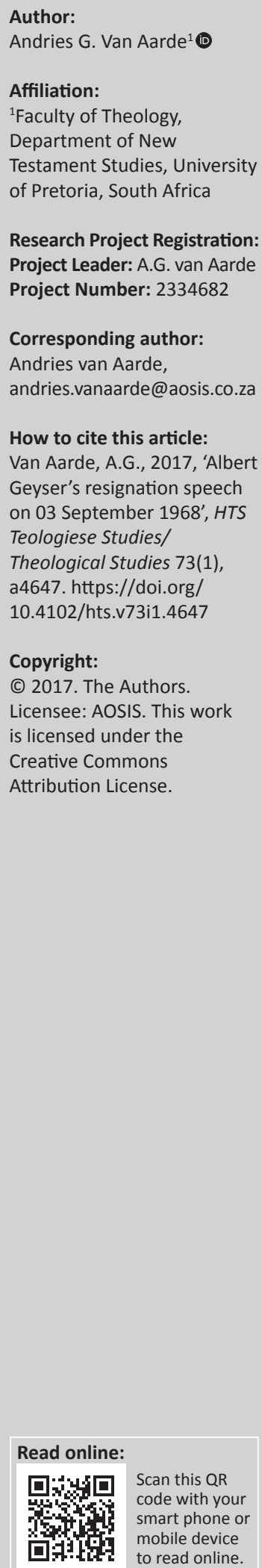

On 01 October 1962, Albert Geyser resigned as professor of the University of Pretoria after having been found guilty of the charge of heresy. The Rector Professor C.H. Rautenbach, under pressure from church leadership, made it impossible for him to stay on. Subsequently, on 26 August 1963, Prof. Adrianus Van Selms resigned as lecturer of the Faculty of Theology. The Executive of the General Assembly of the Hervormde Kerk decided that Van Selms's resignation as lecturer meant that his status as ordained minister of the Hervormde Kerk, was automatically rescinded.

Geyser appealed to the Supreme Court against the Church's guilty verdict on the heresy charge. The judge ordered the advocates to negotiate a retraction of the Church's verdict. The Church agreed and Geyser's status as minister of the Church was restored. Johan Buitendag, in Van Aarde, De Villiers and Buitendag (2014), points out on account of the written memoirs of Judge Frik Eloff that:

we ought to understand the reinstatement of Geyser's ministerial office in much more radical terms than we have done so far ... It is quite clear: Prof. Geyser was not reinstated in his office as if he were the recipient of a favour, but in the sense that he had never been found guilty. It is not a question of a post hoc reinstatement, but rather an ante hoc reinstatement. (p. 9)

On 15 February 1967, Prof. Geyser and the Rev. Beyers Naudé brought a charge of defamation against Prof. Pont. According to Pont, they were communists and in collaboration with the World Council of Churches, in favour of violent revolution. In the ensuing court case, Pont was aided financially by the Church. On 10 June 1967, the Church officially declared their support and officially decided not to rescind this declaration even after the guilty verdict by the Supreme Court against Pont on animus iniuriandi and an ecclesial discipline hearing. Pont failed an appeal to the Appellate Division (the predecessor of the Supreme Court of Appeal) (see Mukheibir 2007:192-193). These actions resulted in the resignation of Prof. van Selms and Dr Cas Labuschagne as members of the Church. On his request, Geyser addressed the Executive of the General Assembly on 03 September 1968. He accused the Executive of having misled the Church the past 12 years and that they were responsible for the Church being presented to the outside world as a 'false church', which goes against both Scripture and the Confessions. He demanded confession of culpability and conversion from the church leadership. ${ }^{1}$ Yet, Geyser stated that he did not want to bring a formal charge against the Church. He said that he had put his thoughts in writing. He proceeded to read the following declaration: ${ }^{2}$

'Chair and members of the Executive of the Netherdutch Reformed Church of Africa, I thank you for this opportunity. I will not take up more of your time than is strictly necessary.'

'The aim and content of my conversation with you this afternoon is for me - and may God grant that it will also be for you - of great consequence.'

'I deem it such a great responsibility that I ask your permission to rather read it than speak freely.'

'In answer to your written enquiry, I wrote you that I will address you regarding three matters':

1. Your leadership of the Netherdutch Reformed Church.

2. Your actions in the Pont case.

3. My position in the Netherdutch Reformed Church as a result of both these matters.

'Directly after Evanston [that is the Second Assembly of the World Council of Churches - founded in 1948 in Amsterdam - in Evanston, Illinois, United States, August 15-31, 1954], the then Executive, of which some of you were members, steered the Netherdutch Reformed Church toward becoming a group that supports the party political ideology of race segregation, also in the Church.'

1.NHKA Minutes General Commission (1968:131-135). Prof. Geyser announced his resignation from the Netherdutch Reformed Church. 2.My translation from the original Afrikaans. 
'Doubts in the Church as to its biblical and confessional legitimacy were suppressed by you, making use of the power of your position and the Church Order, as well as of some external means. At times, you rode roughshod over truths and facts and did not spare persons or any expense.'

'The heresy process you put me through and the subsequent court case in 1963 detracted much of the good reputation of the Netherdutch Reformed Church and cost it ministers, members and assets. Most of you are familiar with this, so I will not belabour the point.'

'Your leadership of the General Assembly of 1964 further damaged the good name of the church. Since 1964, you have allowed Prof. Pont to continue publishing defamatory lies against myself and others.'

Our recent history, known to you all, is the consequence of this.

'What is of importance now is that your actions and leadership in the Pont case further damaged the reputation of the Church. In no single instance did you confront Prof. Pont with the injunctions of God's Word or the confessions of faith, specifically the Heidelberg Catechism, regarding lies and slander. In your interpretation of your task of church discipline, lies and slander do not seem to be deemed sin. The fact that I sued Prof. Pont for damages, on the other hand, was deemed 'grievous sin' (ergerlike sonde). For that you barred me from the ministerial office for two years, pending your internal hearing.'

'Rather than reigning in Prof. Pont, let alone chastising him, you, chairperson, declared at two consecutive ministers' meetings (predikantevergadering) that the Executive fully supports Prof. Pont. Members of the Executive guided the General Assembly to underwrite the actions of Prof. Pont. You wanted to grant him your unconditional support, but your advocate advised you to request that the editor of Die Hervormer pursue a settlement and render an apology.'

'Directly after he did that four of you and one of your officials constituted yourselves with others as a 'fund raising committee for Prof. Pont'. Through this action you again identified yourselves with his cause, thought this time outside of the legal sphere.'

'The verdict of the highest courts of this country was that Prof. Pont maliciously and grievously slandered the Rev. Naudé and myself. The highest compensation yet in a defamation case in South Africa was awarded. Both courts found repeatedly that he was an unreliable witness - that he lied in court while under oath.

'But even then you did not execute church discipline against him. You could not, because by then you were not only legally, but wholly compromised by your identification with his actions.'

'Not much respect for your leadership of the Netherdutch Reformed Church can remain.'

'All of this, chairperson and members of the Executive, I do not say to offend you, but rather to urge you for the second and last time as a minister of the Netherdutch Reformed Church, to turn away from the path that you as leaders, as Executive of the Church, have chosen the past twelve years and to turn to God. My first appeal was made at the General Assembly of 1964. I repeat it here, more urgently, and accompanied by fervent prayer.'

'Your conscience will not refuse to move you - furthermore: the living Word of God will not refrain from refreshing you and the confession that you profess to uphold, namely the Belgic Confession (Nederlandse Geloofsbelydenis), will not desist from proclaiming to you prophetically, accurately and unmistakably, that you as Executive have increasingly over the past twelve years born the mark of a false church.'

'Many ministers and members of the Netherdutch Reformed Church have already left the Church because of you. My wife and I have not left yet, in spite of your leadership. We had hoped that you would relent in the face of the verdict of the courts and court orders against Prof. Pont. However, time has passed and we have not seen any sign of a change of heart. My wife and I now presume - and may God forgive us if our assumption is incorrect - that, for us, under your leadership the Netherdutch Reformed Church no longer represents part of the Church of Christ and that we, therefore, are obliged to leave the Church in obedience to God.'

'I have chosen not to communicate this to you in writing, because I regard it as the last duty of a servant of the Word to bring this call to conversion in person.'

'With my announcement that we are hereby terminating our membership of the Netherdutch Reformed Church and that I then also cease to be an office bearer of the church, I beseech you to think again: you cannot turn the Bride of Christ into a servant to party political ideology.'

'For the sake of God, Christ and the Church, repent and turn to God!'

The chair person speaks for the whole Executive when he states that they cannot agree with Prof. Geyser's interpretation of the matter, because it does not take the facts into account. As Prof. Geyser and his family have long since distanced themselves from the daily life of the Church, they could probably have found another to terminate their membership. For some years, the impression was that Prof. Geyser no longer identified with the Church and its work; though he remained a minister of the Church, the Church only heard from him from time to time, in his ongoing crusade against the Church. Terminating his membership is therefore not a great loss, but rather the logical consequence of his actions of the past years. Maybe his leaving will bring him peace of mind, though it is sad that he finds it necessary to reproach and disparage the Church that is no different to the one in which he grew up.

He will have to justify to himself how this Church that did not change has become a false church in his eyes. The Executive notes that Prof. and Mrs Geyser have terminated their membership of the Church.

\section{References}

Mukheibir, A., 2007, 'The wages of delict: Compensation, satisfaction, punishment?', Academisch proefscrift ter verkrijging van de graad van doctor aan de Universiteit van Amsterdam, PhD thesis, Faculteit der Rechtsgeleerdheid, Universiteit van Amsterdam, viewed 24 September 2014, from http://hdl.handle.net/11245/2.52524

NHKA Minutes General Commission, 1968, Archive of the Nederduitsch Hervormde Kerk van Afrika, pp. 131-135, Pretoria.

Van Aarde, A.G., De Villiers, P.G.R. \& Buitendag, J., 2014, 'The forgotten struggle of Albert Geyser against racism and apartheid', HTS Teologiese Studies/Theological Studies 70(1), Art. \#2820, 1-10. https://doi.org/10.4102/hts.v70i1.2820 